\title{
The Peterson Ranch Site (41HS253), A Late 17th to Early 18th Century Ancestral Caddo Cemetery in the Little Cypress Creek Basin, Harrison County, Texas
}

Timothy K. Perttula

Heritage Research Center, Stephen F. Austin State University

Follow this and additional works at: https://scholarworks.sfasu.edu/ita

Part of the American Material Culture Commons, Archaeological Anthropology Commons, Environmental Studies Commons, Other American Studies Commons, Other Arts and Humanities Commons, Other History of Art, Architecture, and Archaeology Commons, and the United States History Commons

Tell us how this article helped you.

This Article is brought to you for free and open access by the Center for Regional Heritage Research at SFA ScholarWorks. It has been accepted for inclusion in Index of Texas Archaeology: Open Access Gray Literature from the Lone Star State by an authorized editor of SFA ScholarWorks. For more information, please contact cdsscholarworks@sfasu.edu. 
The Peterson Ranch Site (41HS253), A Late 17th to Early 18th Century Ancestral Caddo Cemetery in the Little Cypress Creek Basin, Harrison County, Texas

\section{Creative Commons License}

\section{(c) (1) \&}

This work is licensed under a Creative Commons Attribution-NonCommercial 4.0 International License 


\title{
The Peterson Ranch Site (41HS253), A Late 17th to Early 18th Century Ancestral Caddo Cemetery in the Little Cypress Creek Basin, Harrison County, Texas
}

\author{
Timothy K. Perttula
}

\section{INTRODUCTION}

The Peterson Ranch site (41HS253) is a late 17th to early 18th century Caddo cemetery in the Little Cypress Creek basin in the East Texas Pineywoods (Figure 1). The cemetery, on Gray's Creek, was found and excavated in 1962 by a number of collectors from the Marshall, Texas, area. In 1963 the cemetery area was destroyed by the construction of an oil well pad.

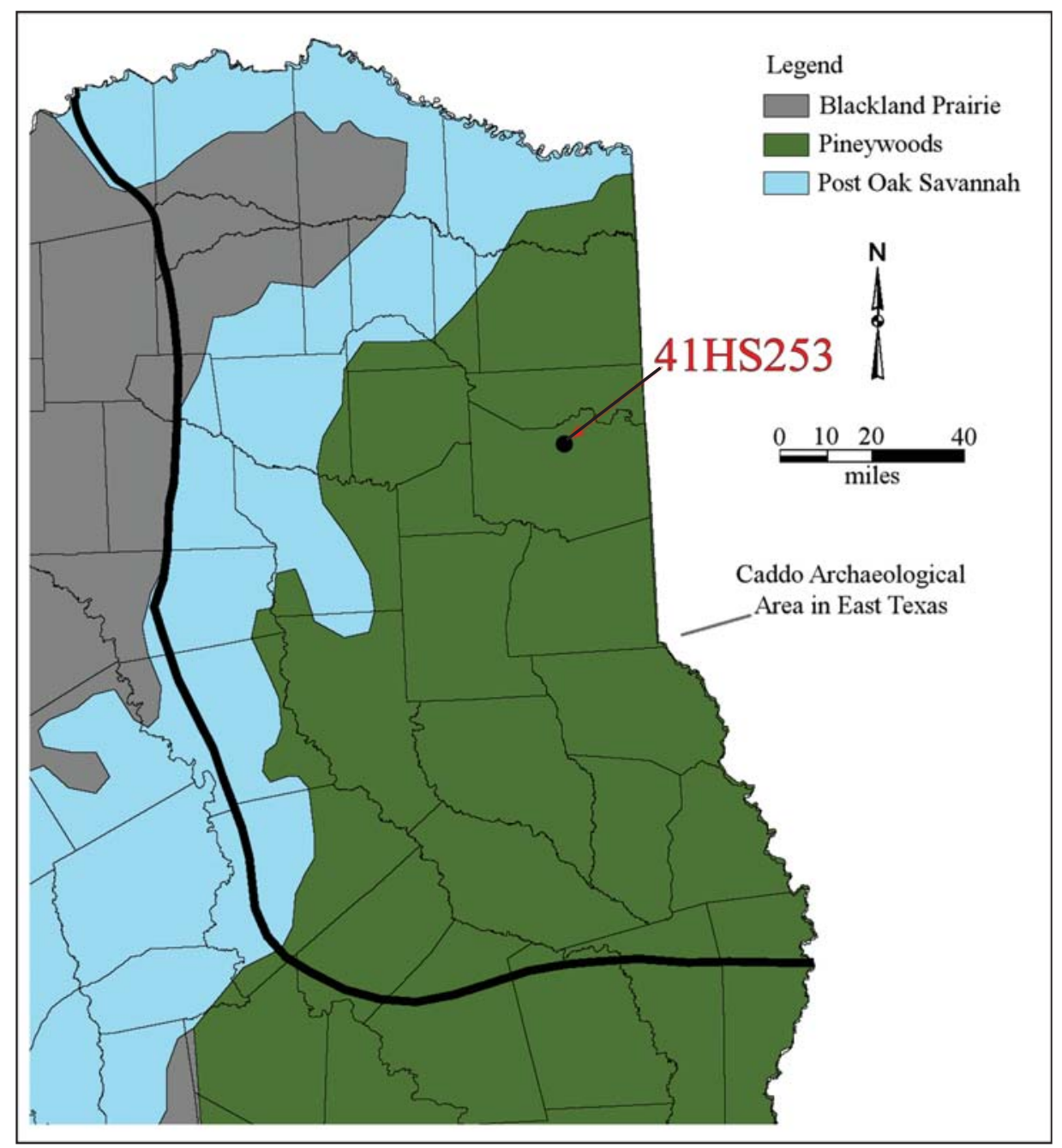

Figure 1. The location of the Peterson Ranch site (41HS253) in East Texas. 
Most of the collectors kept cursory notes on their excavations at the site, which consisted of plan maps showing the orientation of the burial pits, the human remains in the graves, and the location and kinds of some of the funerary offerings placed in the grave to accompany the deceased to the House of Death in the Sky (e.g., Gonzalez et al. 2005; Parsons 1941; Swanton 1942:205). Fray Casanas (1927:294) commented in 1691 that the Caddo buried "their dead with all their arms and utensils which each possesses." The kinds of items placed in Caddo burials, especially the vessels - since they are by far the most common burial offerings - can provide unique insights into how different Caddo groups treated the dead, and what such differences may mean regarding diverse view on life and death among contemporaneous Caddo groups.

The information on the cemetery excavations and burial offerings from the Peterson Ranch site has been reconstructed from notes and drawings on file at the Texas Archeological Research Laboratory at The University of Texas at Austin (TARL) (Speir n.d.). To my knowledge, the funerary offerings from the burials at the site have not been documented by a professional archaeologist, and it is presently unknown what the current provenience(s) of the collections are.

\section{CEMETERY EXCAVATIONS}

The Peterson Ranch site cemetery was situated on a natural knoll on the west side of Gray's Creek, a northward-flowing tributary of Little Cypress Creek. There are notes in the TARL files on 14 burials, but Forrest Murphey, one of the collectors that worked at the site, stated in 1982 that 15-20 burials had been excavated there.

The knoll covered a ca. $87 \times 27 \mathrm{~m}$ area, and stood ca. $1.8 \mathrm{~m}$ in height. The cemetery itself was apparently on the crest of the knoll and covered a ca. 25 x 15 m area (Figure 2).

The burial pits were oriented generally east-west and the deceased individuals were laid in the pits in an extended supine position with their heads facing generally to the west. In the case of Burial 3, however, which was in the same pit as Burial 2, but underneath it, the head of that individual faced generally to the east. The Burial 13 skeletal remains were covered with red ochre.

A wide range of funerary offerings were included with the deceased individuals (Table 1), although there was no formal accounting of the number of all the offerings in Speir (n.d.) or in the collector's burial plans. There is no information available on the funerary offerings in Burials 6 and 10.

In the 11 Caddo burials from the Peterson Ranch site that have some level of information available concerning the funerary offerings placed with the deceased, ceramic vessels ( $>91$ vessels) are by far the most common funerary offering. ${ }^{1}$ The range of vessels per burial is 5-17, with a mean of 8.3 vessels per burial. None of the burial plans showed arrow points or other stone tools, though based on the likely age of the cemetery (see discussion below), it is likely that there were at least celts and large chipped bifaces among the funerary offerings (cf. Perttula et al. 2010).

Other funerary offerings include mussel shell hoes with a circular perforated hole at one end (cf. Perttula et al. 2010:Figure 32). A sturdy wood stick would have been placed through the perforation to haft the shell to it, creating a wood-handled hoe. Unmodified mussel shells were also placed in four of the graves, and several of these held a green pigment (a glauconitic clay) or were used as spoons (Webb 1959:175). Such offerings were relatively common in the burials at the contemporaneous Clements site (41CS25) and the Goode Hunt site (41CS23), and some held green or red pigments; they were also found in association with deer mandibles (Perttula et al. 2010:36).

Two of the burials, certainly members of the social elite in the ancestral Caddo community that used the cemetery, had marine shell bead belts (see Table 1) that were worn across the mid-section of the deceased 


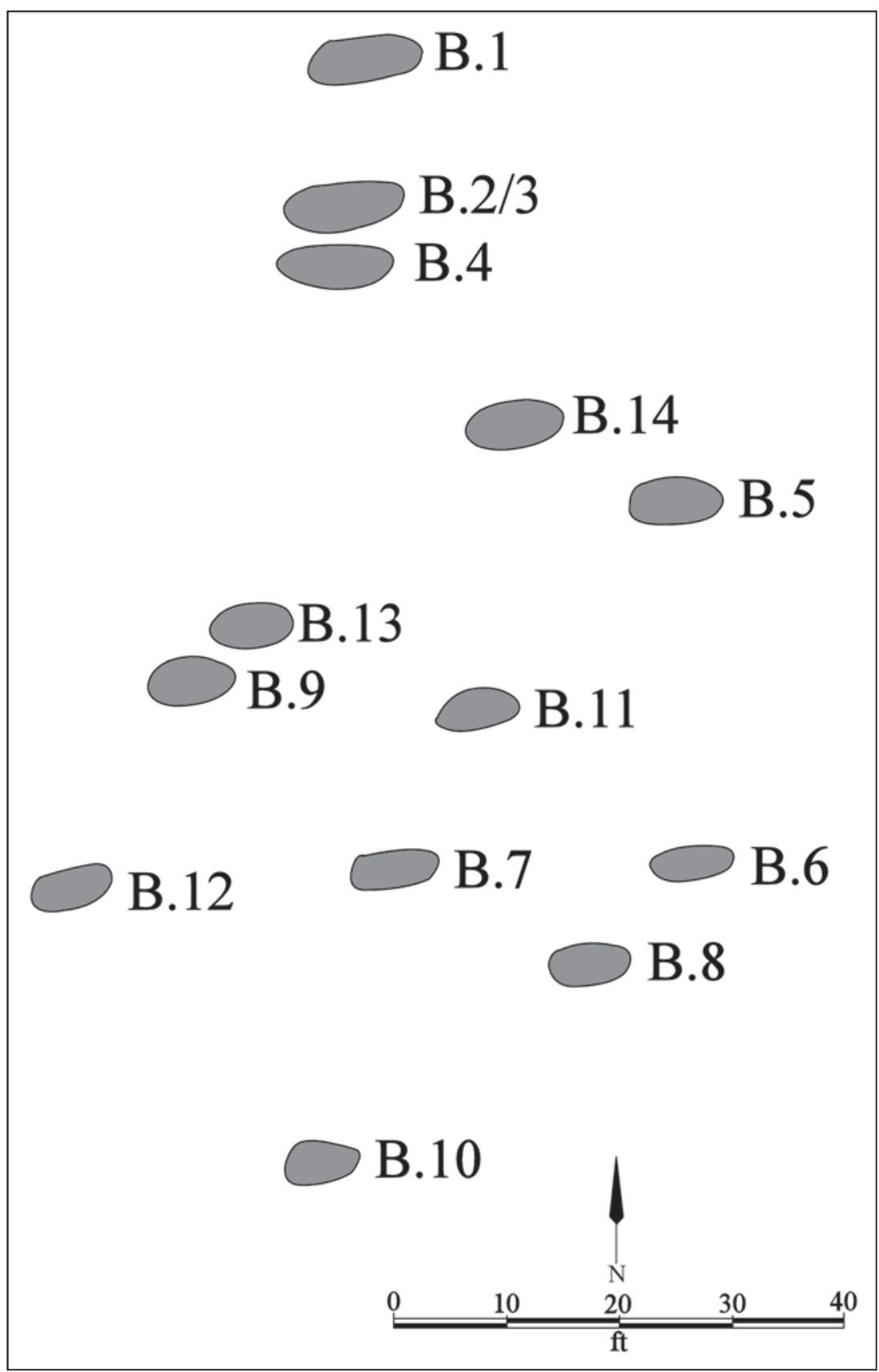

Figure 2. Plan of the burials excavated at the Peterson Ranch site.

when they were laid in the grave. One of these burials (Burial 9) also had a deer antler and a clay elbow pipe, while the other (Burial 13) had a deer mandible offering and two copper-covered ear spools with a cypress wood backing. Burial 7 had a silver disk resting on its chest.

\section{CERAMIC VESSELS IN THE BURIALS}

Notes on the burial plans, as well as a few drawings of decorative elements on a few of the ceramic vessels (Speir n.d), allow the gleaning of some substantive information about the unique character of the vessel assemblage from the Peterson Ranch site. Among the utility ware vessels are mention of a brushed 
Table 1. Funerary offerings from burials at the Peterson Ranch site.

\begin{tabular}{|c|c|c|c|c|c|c|}
\hline Burial No. & Vessels & $\begin{array}{l}\text { Shell } \\
\text { hoe }\end{array}$ & $\begin{array}{c}\text { Mussel } \\
\text { shells }\end{array}$ & $\begin{array}{c}\text { Green } \\
\text { pigment }\end{array}$ & $\begin{array}{c}\text { Marine } \\
\text { shell beads }\end{array}$ & Other \\
\hline 1 & 5 & 1 & 3 & $*$ & - & - \\
\hline $2 / 3$ & $6+$ & 1 & $*$ & - & - & - \\
\hline 4 & 5 & - & - & - & - & - \\
\hline 5 & 8 & - & - & - & - & - \\
\hline 7 & 8 & 1 & $*$ & $*$ & - & $\mathrm{Sd}$ \\
\hline 8 & 9 & 1 & - & $*$ & - & $\mathrm{Dm}$ \\
\hline 9 & 8 & - & - & - & $*$ & $\begin{array}{r}\text { Pipe, } \\
\text { Da }\end{array}$ \\
\hline 11 & 5 & - & 1 & $*$ & - & - \\
\hline 12 & 16 & - & - & - & - & - \\
\hline 13 & 17 & - & - & $*$ & $*$ & $\begin{array}{l}\text { Dm, } \\
\text { C Es }\end{array}$ \\
\hline 14 & 4 & - & - & - & - & - \\
\hline Totals & $91+$ & 4 & $>4$ & $*$ & $*$ & $\begin{array}{r}2 \mathrm{Dm}, \\
1 \mathrm{Da}, \\
1 \mathrm{Pipe}, \\
2 \mathrm{C} \mathrm{Es}, 1 \mathrm{Sd}\end{array}$ \\
\hline
\end{tabular}

$+=$ does not include an unknown number of broken vessels shown on the burial plan

$*=$ present

C Es=copper ear spools; $\mathrm{Da}=$ deer antler; $\mathrm{Dm}=$ deer mandible; $\mathrm{Sd}=$ silver disk

jar in Burial 2/3; Bullard Brushed jars in Burial 4, Burial 12, and Burial 13; a Cass Appliqued jar in Burial 13; a Clements Brushed olla in Burial 13 (Vessel 4); a large La Rue Neck Banded jar in Burial 5; Maydelle Incised jars in Burial 8 and Burial 13; an incised jar in Burial 13 (Vessel 10); and an incised-punctated jar in Burial 13 (Vessel 15). This latter vessel had three rows of tool punctations on the rim, and the vessel body had cross-hatched incised lines. The occurrence of both Cass Appliqued and Clements Brushed vessels suggest a late 17th-early 18th century age for Burial 13, at least (cf. Perttula et al. 2010:Figures 18 and 24b; Suhm and Jelks 1962:25, 27).

The fine ware vessels from the Peterson Ranch are stylistically diverse. There are Simms Engraved carinated bowls $(\mathrm{n}=10)$, including a number of vessels in the late 17th-early 18th century hubcap style (see Suhm and Jelks 1962:Plate 71b-c), from Burial 1, Burial 7, Burial 8, Burial 9, Burial 12, and Burial 13; Keno Trailed bowls from Burials 2/3 and Burial 4; a Hodges Engraved bottle with a spool neck in Burial 5; a Taylor Engraved compound bowl in Burial 8; a spool necked bottle, possibly of the Bailey Engraved type, from Burial 13 (Vessel 3) (Figure 3a); a red-slipped Avery Engraved deep bowl in Burial 13 (Figure 3b); and a red-slipped Natchitoches Engraved carinated bowl from Burial 14 (Figure 4).

\section{SUMMARY AND CONCLUSIONS}

The Peterson Ranch site (41HS253) is an ancestral Caddo family cemetery on a natural knoll alongside a tributary stream of Little Cypress Creek in Harrison County, Texas. The cemetery was excavated by a number of collectors from the Marshall, Texas, area, and it is estimated that between 15-20 burials were 


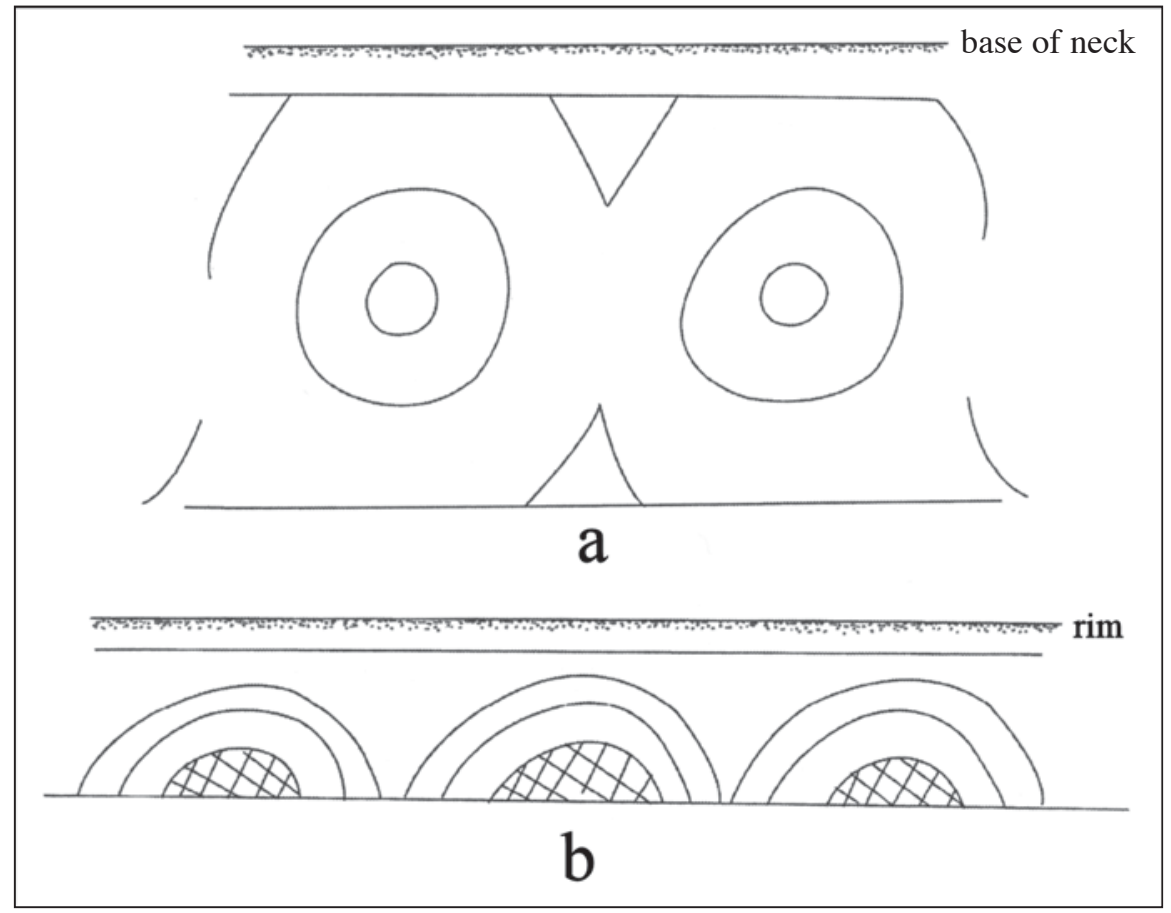

Figure 3. Decorative elements on two vessels from Burial 13 at the Peterson Ranch site: a, engraved spool necked bottle (Vessel 3); b, Avery Engraved deep bowl (Vessel 5).

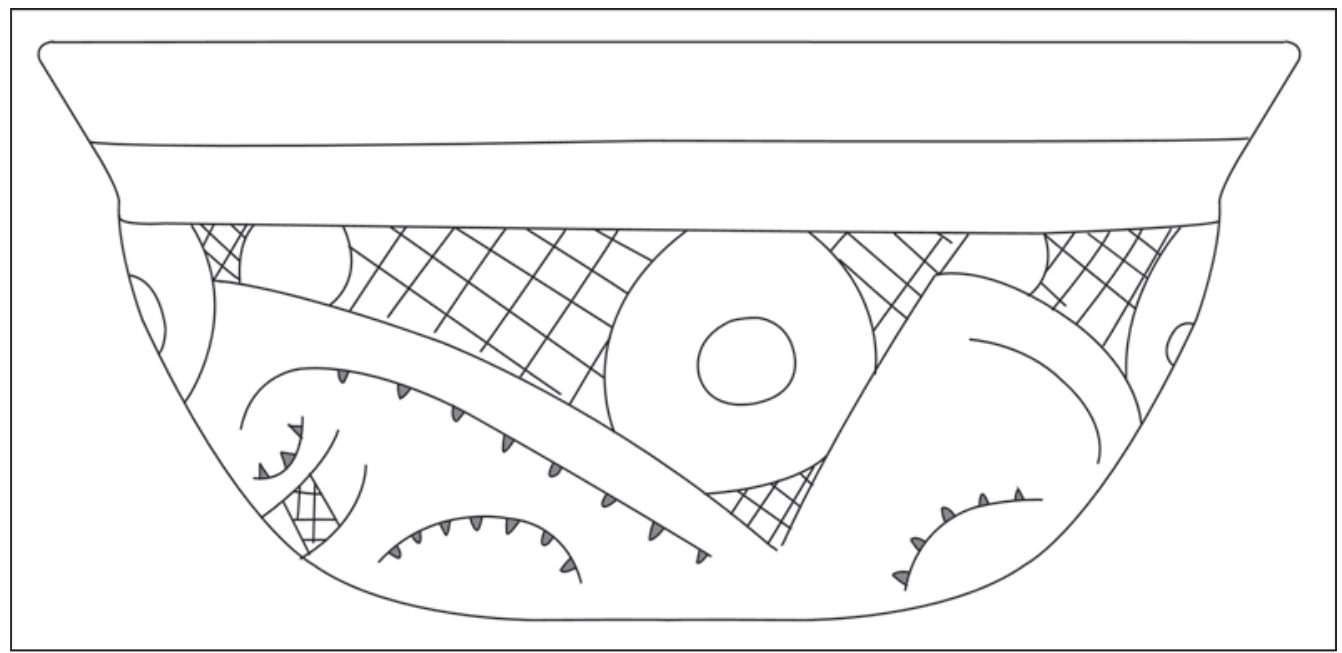

Figure 4. Natchitoches Engraved carinated bowl from Burial 14 (Vessel 1) at the Peterson Ranch site.

excavated at the site in 1962; the cemetery area was destroyed the following year by the construction of an oil well pad. These burials were in graves oriented east-west, with the head of the deceased generally facing to the west. Although the available records on the 1962 excavations are rather skimpy, it is the case that these ancestral Caddo interments were accompanied by a variety of funerary offerings, primarily ceramic vessels (and their contents), a clay elbow pipe, mussel shell hoes, unmodified mussel shell valves (holding clay pigments), deer mandibles and deer antlers, clay pigments, marine shell bead belts, copper-covered 
earspools, and a silver disk. The range and kind of funerary offerings in the graves at the Peterson Ranch site are comparable to those from the contemporaneous Clements site (41CS25) in the Black Bayou basin, ca. $40 \mathrm{~km}$ to the north in the East Texas Pineywoods.

The most abundant funerary offerings are ceramic vessels, including both utility ware and fine ware vessels. Overall, the range of decorated ceramic vessels identified in Speir (n.d.) as coming from the Caddo burials at the Peterson Ranch site are comparable to vessels recovered from late Texarkana (ca. A.D. 16001700), Belcher (ca. A.D. 1600-1700), and Chakanina (late 17th-early 18th century A.D.) phase burials on the Red River at sites such as Hatchel (41BW3), Eli Moores (41BW2), Belcher (16CD13), and Cedar Grove (3LA97), and from the Clements and Goode Hunt sites on Black Bayou (Perttula 2014, 2015; Perttula et al. 2010:19; Schambach and Miller 1984; Webb 1959). It appears to be the case that the Peterson Ranch and Clements sites closely share ceramic stylistic relationships, and it is likely that these sites are from neighboring Caddo communities or groups, perhaps Nasoni Caddo communities or groups (Perttula et al. 2010:19-20), whose members had strong bonds of kinship, interaction, and lineal relationships.

\section{END NOTES}

1. Forrest Murphey donated a large brushed jar from the site to TARL, but it is not known what burial it was found with. The jar, $29.9 \mathrm{~cm}$ in height and $27.0 \mathrm{~cm}$ in orifice diameter, has vertical brushing marks on the rim and diagonal brushing marks on the vessel body. Two other vessels, and a flat clay turtle effigy, were found by one of the collectors in 1964 at the site after the oil well pad was constructed.

\section{ACKNOWLEDGMENTS}

I thank Lance Trask for preparing the figures for this article. I also appreciate access to the records at TARL facilitated by Jonathan Jarvis.

\section{REFERENCES CITED}

Casanas, Fray

1927 Descriptions of the Tejas or Asinai Indians, 1691-1722. Translated and edited by M. A. Hatcher. Southwestern Historical Quarterly 30-31.

Gonzalez, B., R. L. Cast, T. K. Perttula, and B. Nelson

2005 A Rediscovering of Caddo Heritage: The W. T. Scott Collection at the American Museum of Natural History and Other Caddo Collections from Arkansas and Louisiana. Historic Preservation Program, Caddo Nation of Oklahoma, Binger.

Parsons, E. C.

1941 Notes on the Caddo. Memoir 57. American Anthropological Association, Washington, D.C.

Perttula, T. K.

2014 Archaeological Studies of the Hatchel Site (41BW3) on the Red River in Bowie County, Texas. Special Publication No. 23. Friends of Northeast Texas Archaeology, Austin and Pittsburg.

2015 The Eli Moores Site, a 17th to early 18th century Caddo Site on the Red River, Bowie County, Texas. Special Publication No. 31. Friends of Northeast Texas Archaeology, Austin and Pittsburg.

Perttula, T. K., B. Nelson, R. L. Cast, and B. Gonzalez

2010 The Clements Site (41CS25): A Late 17th to Early 18th-Century Nasoni Caddo Settlement and Cemetery. Anthropological Papers No. 92. American Museum of Natural History, New York. 
Schambach, F. F. and J. E. Miller

1984 A Description and Analysis of the Ceramics. In Cedar Grove: An Interdisciplinary Investigation of a Late Caddo Farmstead in the Red River Valley, edited by N. L. Trubowitz, pp. 109-170. Research Series No. 23. Arkansas Archeological Survey, Fayetteville.

Speir, $\mathrm{T}$.

n.d. Peterson Ranch Site (41HS253). MS on file, Texas Archeological Research Laboratory, The University of Texas at Austin.

Suhm, D. A. and E. B. Jelks (editors)

1962 Handbook of Texas Archeology: Type Descriptions. Special Publication No. 1, Texas Archeological Society, and Bulletin No. 4, Texas Memorial Museum, Austin. Reprinted in 2009, Gustav's Library, Davenport, Iowa.

Swanton, J. R.

1942 Source Material on the History and Ethnology of the Caddo Indians. Bulletin 132. Bureau of American Ethnology, Smithsonian Institution, Washington, D.C.

Webb, C. H.

1959 The Belcher Mound, a Stratified Caddoan Site in Caddo Parish, Louisiana. Memoirs No. 16. Society for American Archaeology, Salt Lake City. 